\title{
Characterization of an Extracellular $\beta$-Amylase from Bacillus megaterium sensu stricto
}

\author{
By MARY THOMAS, F. G. PRIEST* AND J. R. STARK \\ Department of Brewing and Biological Sciences, Heriot-Watt University, \\ Chambers Street, Edinburgh EH1 $1 H X$
}

(Received 28 August 1979; revised 30 October 1979)

\begin{abstract}
Bacillus megaterium sensu stricto (NCIB 7581) produced amylase throughout exponential growth and during the early-stationary phase. Enzyme synthesis occurred in the absence of $\alpha$-glucans but the yield was maximal when malt extract or starch was supplied as carbon source. Of the nitrogen sources examined, soya flour stimulated the highest yield of amylase. The enzyme was susceptible to reagents that react with thiol groups and had an exo-action on starch yielding maltose with a $\beta$-anomeric configuration. It is concluded that the principal starch-hydrolysing enzyme from $B$. megaterium NCIB 7581 is a $(1 \rightarrow 4)$ - $\alpha$-D-glucan maltohydrolase similar in its properties to other Bacillus and plant $\beta$-amylases.
\end{abstract}

\section{INTRODUCTION}

Bacillus megaterium is a diverse species consisting of at least two aggregates of strains (Gordon et al., 1973). Those organisms that fail to accumulate nitrite from nitrate but deaminate phenylalanine represent $B$. megaterium sensu stricto while strains giving the opposite reactions conform to the description of $B$. carotarum (Gibson \& Gordon, 1974). Although $B$. carotarum is often accepted as a synonym of $B$. megaterium (Smith et al., 1952), recent numerical analyses (Logan \& Berkeley, 1980; Priest et al., 1980) and DNA homology studies (Claus \& Hunger, 1980) clearly separate these taxa.

When grown on starch agar, B. megaterium produces a clear hydrolysis zone around the colony. Bacillus carotarum strains, on the other hand, are characterized by a weak zone of starch hydrolysis that retains some iodine-staining capacity (Gibson \& Gordon, 1974), a feature that is consistent with $\beta$-amylase [(1-4)- $\alpha$-D-glucan maltohydrolase] secretion. Furthermore, a soil bacterium hitherto identified as $B$. megaterium reduces nitrate to nitrite and in several other respects conforms to the description of $B$. carotarum. This organism secretes $\beta$-amylase (Higashihara \& Okada, 1974). The starch-degrading enzymes from $B$. megaterium sensu stricto have not been characterized. Strain NCIB 7581 (ATCC 15374) has been studied by Gordon et al. (1973) and fits the description of $B$. megaterium sensu stricto. In this paper we show that strain NCIB 7581 secretes a $\beta$-amylase.

\section{METHODS}

Organism and growth conditions. Bacillus megaterium NCIB 7581 was obtained from the National Collection of Industrial Bacteria, Torry Research Station, Aberdeen. Bacillus megaterium NRS 986 was provided by R. E. Gordon. Bacteria were maintained on nutrient agar (Oxoid) at $4{ }^{\circ} \mathrm{C}$. Strain NCIB 7581 was grown in basal medium (Takasaki, 1976a) comprising (g $\left.1^{-1}\right): \mathrm{K}_{2} \mathrm{HPO}_{4}, 3 ; \mathrm{MgSO}_{4} .7 \mathrm{H}_{2} \mathrm{O}, 1$; biotin, $0.02(\mathrm{pH} 7 \cdot 0)$; and supplemented as indicated in the text. Overnight cultures in nutrient broth (Oxoid no. 2) were used to inoculate indented flasks $(500 \mathrm{ml})$ containing $50 \mathrm{ml}$ medium and these were shaken $\left(180 \mathrm{rev} . \mathrm{min}^{-1}\right)$ at $30{ }^{\circ} \mathrm{C}$ on an orbital incubator for $22 \mathrm{~h}$.

Analytical procedures. Protein was estimated by a modification (Miller, 1959) of the Lowry method. 
Total carbohydrate was assayed by the phenol/sulphuric acid method (Dubois et al., 1956). Paper chromatograms were developed in ethyl acetate/pyridine/water (10:4:3, by vol.) using Whatman no. 1 paper and the sugars were treated with silver nitrate reagent (Trevelyan et al., 1951).

Amylase activity was estimated either by the increase in reducing power or by the decrease in iodinestaining of digests containing starch and culture supernatant solution. In the first method, cells were removed by centrifuging ( $10000 \mathrm{~g}$ for $10 \mathrm{~min}$ ) and the supernatant solution was dialysed against several changes of phosphate buffer $(0.01 \mathrm{M}, \mathrm{pH} 7.0)$ for $24 \mathrm{~h}$ at $4{ }^{\circ} \mathrm{C}$. Dialysed crude extract was stable at $4{ }^{\circ} \mathrm{C}$ for at least $21 \mathrm{~d}$. The assay mixture, comprising $\mathrm{BDH}$ potato starch $[1 \mathrm{ml}$ of a $1 \%(\mathrm{w} / \mathrm{v})$ solution in $0 \cdot 1 \mathrm{M}$-phosphate buffer, pH 7.0] and dialysed culture supernatant solution $(1 \mathrm{ml})$ was incubated at $37^{\circ} \mathrm{C}$ for $30 \mathrm{~min}$. The reaction was halted by heating at $100^{\circ} \mathrm{C}$ for $10 \mathrm{~min}$ before estimating the reducing sugars by a modification of the Nelson-Somogyi method (Robyt \& Whelan, 1968). Controls were prepared using heat-inactivated enzyme and maltose was used as a standard. One unit of amylase activity was defined as the amount of enzyme which liberated $1 \mu \mathrm{mol}$ maltose $\mathrm{min}^{-1} \mathrm{ml}^{-1}$ under the above conditions. For examination of the effect of the enzyme on the iodine-staining power of starch, assay mixtures were set up as above. Samples $(1 \mathrm{ml})$ were removed at intervals and added to distilled water containing $1 \mathrm{M}-\mathrm{H}_{2} \mathrm{SO}_{4}(0.5 \mathrm{ml})$. Iodine solution ( $1 \mathrm{ml}$, containing $0.02 \mathrm{~g} \mathrm{I}_{2} 1^{-1}$ and $0.2 \mathrm{~g} \mathrm{KI}^{-1}$ ) was added, the volume was made to $25 \mathrm{ml}$ with water and the absorbance was read at $600 \mathrm{~nm}$ against an appropriate water/iodine blank.

Partial purification of enzyme. The enzyme was partially purified from the supernatant of a culture incubated at $30^{\circ} \mathrm{C}$ for $18 \mathrm{~h}$. Culture fluid [40 ml, $860 \mu \mathrm{g}$ protein $\mathrm{ml}^{-1}$, sp. act. 0.715 units $(\mathrm{mg} \text { protein })^{-1}$ ] was loaded on to a DEAE-cellulose (DE 52) column which had been equilibrated with $20 \mathrm{~mm}$-citrate/ phosphate buffer ( $\mathrm{pH} \mathrm{8.0)}$ containing mercaptoethanol (10 mM). Fractionation was carried out using the above buffer and this resulted in elution of $7 \cdot 3 \%$ of the total protein applied. Amylase activity was recovered as a major peak (fraction I) with a specific activity of $10 \cdot 15$ units (mg protein) ${ }^{-1}$ representing a 14-fold purification. A minor peak (fraction II), which eluted shortly after fraction I, had a specifc activity of 2.44 units $(\mathrm{mg} \text { protein })^{-1}$. The total recovery of amylase activity was $68 \%$.

Enzyme characterization. To measure the extent of degradation of starch and amylose, digests containing substrate $(80 \mathrm{mg})$ in phosphate buffer $(0 \cdot 1 \mathrm{M}, \mathrm{pH} 7 \cdot 0,8 \mathrm{ml})$ and fraction $\mathrm{I}(8 \mathrm{ml}, 272 \mu \mathrm{g}$ protein) or fraction II $\left(8 \mathrm{ml}, 240 \mu \mathrm{g}\right.$ protein) were incubated at $37^{\circ} \mathrm{C}$ for $48 \mathrm{~h}$ in the presence of toluene.

Maltosaccharides $(5 \mathrm{mg})$ and maltosyl-Schardinger dextrin $(10 \mathrm{mg})$ dissolved in water $(100 \mu \mathrm{l})$ were incubated with fraction I $(10 \mu \mathrm{l})$ or fraction II $(10 \mu \mathrm{l})$ for $24 \mathrm{~h}$ at $37^{\circ} \mathrm{C}$ in an atmosphere of toluene. Products were analysed by paper chromatography.

Enzyme inhibition by $p$-chloromercuribenzoic acid ( $p$-CMB) was studied according to Higashihara \& Okada (1974). A mixture containing enzyme $(1 \mathrm{ml})$, citrate buffer $(0.1 \mathrm{M}, \mathrm{pH} 4.6,0.6 \mathrm{ml})$ and $p$-CMB solution $(1 \mathrm{~mm}, 0.4 \mathrm{ml})$ was incubated at $22{ }^{\circ} \mathrm{C}$ for $60 \mathrm{~min}$. At intervals, samples $(0.5 \mathrm{ml})$ were removed and assayed for amylase activity. Cysteine $(10 \mathrm{mM}, 1.25 \mathrm{ml})$ and citrate buffer $(0.1 \mathrm{M}, \mathrm{pH} 7.0,0.75 \mathrm{ml})$ were added to inactivated enzyme $(0.5 \mathrm{ml})$. After incubation for $60 \mathrm{~min}$ at $22{ }^{\circ} \mathrm{C}$ the residual activity was estimated.

The mutarotation of the product of enzyme action was observed as the change in optical rotation with time. The reaction mixture contained fraction $\mathrm{I}(0.5 \mathrm{ml})$ and amylopectin $\left(40 \mathrm{mg} \mathrm{ml}^{-1}\right)$ in citrate buffer $(10 \mathrm{~mm}, \mathrm{pH} 6.0,2.5 \mathrm{ml})$. After incubation at $22{ }^{\circ} \mathrm{C}$ for $17 \mathrm{~h}$, the reaction was stopped by the addition of $0 \cdot 1 \mathrm{ml} \mathrm{HgCl}_{2}\left(50 \mathrm{mg} \mathrm{ml}^{-1}\right)$ and the mutarotation of the product was observed over $48 \mathrm{~h}$.

Chemicals. Soya flour, yeast extract, corn steep liquor and waxy maize starch were kindly provided by ABM Chemicals, Stockport, Cheshire. All other medium ingredients were from Oxoid. Maltosaccharides were prepared according to Manners \& Stark (1974) and maltosyl-Schardinger dextrin was obtained from amylopectin $\beta$-amylolysis limit dextrin by the action of Bacillus macerans amylase. Amylose and amylopectin were prepared from broad beans by R. W. Gordon. Laminarin (from Laminaria hyperborea), cellodextrin and barley $\beta$-glucan were laboratory samples obtained from D. J. Manners. Pullulan was prepared from Aureobasidium pullulans.

\section{RESULTS AND DISCUSSION}

The production of amylase when $B$. megaterium was grown in batch culture in basal medium containing peptone $(1 \%, \mathrm{w} / \mathrm{v})$ and malt extract $(0.6 \%, \mathrm{w} / \mathrm{v})$ is shown in Fig. 1 . Enzyme production accompanied exponential growth and continued into the earlystationary phase reaching a maximum yield $12 \mathrm{~h}$ after exponential growth had ceased. During growth, the $\mathrm{pH}$ of the culture dropped initially and subsequently increased to reach $\mathrm{pH} 7.8$ after $24 \mathrm{~h}$ incubation. This pattern of amylase production was similar to that reported for Bacillus cereus var. mycoides (Shinke et al., 1975a; Takasaki, 1976b) and Bacillus polymyxa (Griffin \& Fogarty, 1973) and contrasts with the typical pattern of $\alpha$-amylase synthesis exemplified by Bacillus subtilis and Bacillus amyloliquefaciens in which 


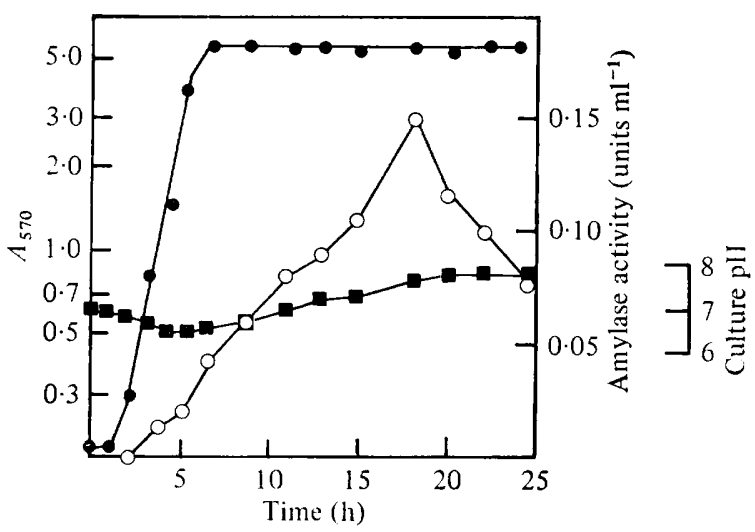

Fig. 1. Growth of $B$. megaterium and extracellular amylase secretion in basal medium containing peptone $(1 \%, \mathrm{w} / \mathrm{v})$ and malt extract $(0.6 \%, \mathrm{w} / \mathrm{v}):-$, culture density; $\bigcirc$, amylase activity in medium; $\mathbf{\square}, \mathrm{pH}$ of culture.

Table 1. Effect of nitrogen source on amylase synthesis by B. megaterium

The basal medium was supplemented with starch $(0 \cdot 5 \%, \mathrm{w} / \mathrm{v})$ and cultures were incubated for $20 \mathrm{~h}$.

$\begin{array}{lccc}\begin{array}{c}3 \\ \text { Nitrogen source } \\ (2 \%, \mathrm{w} / \mathrm{v})\end{array} & \begin{array}{c}\text { Biomass } \\ (\mathrm{mg} \mathrm{dry} \text { wt } \\ \left.\mathrm{ml}^{-1}\right)\end{array} & \begin{array}{c}10^{3} \times \\ \text { units } \mathrm{ml}^{-1}\end{array} & \begin{array}{c}\text { Amylase activity } \\ \text { units }(\mathrm{mg} \\ \text { biomass })^{-1}\end{array} \\ \text { Soya flour } & 2 \cdot 4 & 68 \cdot 6 & 28 \cdot 6 \\ \text { Peptone } & 2 \cdot 4 & 33 \cdot 8 & 14 \cdot 1 \\ \text { Lab-lemco } & 2 \cdot 4 & 30 \cdot 9 & 12 \cdot 9 \\ \text { Casein hydrolysate } & 2 \cdot 0 & 18 \cdot 2 & 9 \cdot 1 \\ \text { Skim milk } & 1 \cdot 8 & 16 \cdot 4 & 9 \cdot 1 \\ \text { Yeast extract } & 2 \cdot 1 & 14 \cdot 9 & 7 \cdot 1 \\ \text { Corn-steep liquor } & 2 \cdot 8 & 10 \cdot 4 & 3 \cdot 7 \\ \left(\mathrm{NH}_{4}\right)_{2} \mathrm{SO}_{4} & 1 \cdot 3 & 6 \cdot 7 & 5 \cdot 2 \\ \text { Urea }^{4} & 1 \cdot 4 & 5 \cdot 7 & 4 \cdot 1\end{array}$

maximum enzyme secretion occurs during the stationary phase (Priest, 1977). The rapid decline in amylase activity which occurred during stationary phase was probably the result of proteolytic degradation.

Amylase was produced by strain NCIB 7581 irrespective of the nitrogen source (Table 1), although the yield was lower with less complex media. Soya flour stimulated production of amylase activity and a concentration of $1 \%(\mathrm{w} / \mathrm{v})$ was found to be optimal. Similarly B. cereus var. mycoides (Takasaki, 1976a) and B. polymyxa (Griffin \& Fogarty, 1973) require a complex nitrogen source for optimal $\beta$-amylase production. There are no equivalent data for $\beta$-amylase synthesis by $B$. megaterium no. 32 (Higashihara \& Okada, 1974).

The enzyme was synthesized irrespective of the carbon source composition but the more complex materials provided greater yields (Table 2). Malt extract and starch stimulated maximum production and the optimum concentration of malt extract was found to be $0.6 \%(\mathrm{w} / \mathrm{v}) . \beta$-Amylase synthesis in the absence of exogenous $\alpha$-glucans is exceptional since in both B. cereus var. mycoides (Takasaki, 1976a) and B. polymyxa (Griffin \& Fogarty, 1973) $\beta$-amylase is apparently inducible and its synthesis is dependent on the presence of starch or malto-oligosaccharide in the medium. 
Table 2. Effect of carbon source on amylase synthesis by B. megaterium

The basal medium was supplemented with soya flour $(1 \%, \mathrm{w} / \mathrm{v})$ and cultures were incubated for $20 \mathrm{~h}$.

\begin{tabular}{|c|c|c|c|}
\hline \multirow[b]{2}{*}{$\begin{array}{c}\text { Carbon source } \\
(0.5 \%, \mathrm{w} / \mathrm{v})\end{array}$} & \multirow[b]{2}{*}{$\begin{array}{c}\text { Biomass } \\
\text { (mg dry wt } \\
\left.\mathrm{ml}^{-1}\right)\end{array}$} & \multicolumn{2}{|c|}{ Amylase activity } \\
\hline & & $\begin{array}{c}10^{3} \times \\
\text { units } \mathrm{ml}^{-1}\end{array}$ & $\begin{array}{c}10^{3} \times \\
\text { units (mg } \\
\text { biomass) }\end{array}$ \\
\hline Malt extract & $1 \cdot 4$ & $57 \cdot 4$ & $41 \cdot 0$ \\
\hline Maize starch & $1 \cdot 3$ & $46 \cdot 0$ & $35 \cdot 4$ \\
\hline Potato starch & $1 \cdot 3$ & $34 \cdot 0$ & $26 \cdot 2$ \\
\hline Maltose & $1 \cdot 3$ & $33 \cdot 1$ & $25 \cdot 5$ \\
\hline Glucose & $1 \cdot 4$ & $30 \cdot 8$ & $15 \cdot 7$ \\
\hline Sucrose & $1 \cdot 2$ & $9 \cdot 0$ & $7 \cdot 5$ \\
\hline Lactose & $1 \cdot 5$ & $7 \cdot 5$ & $5 \cdot 0$ \\
\hline Glycerol & $1 \cdot 5$ & $3 \cdot 0$ & $2 \cdot 0$ \\
\hline
\end{tabular}

\section{Properties of the enzyme}

Some properties of the crude enzyme (dialysed culture supernatant) were examined initially. The amylase activity was maximal at $\mathrm{pH} 6.5$ to 7.0 and decreased to about $38 \%$ of the maximum at $\mathrm{pH} \mathrm{5.5}$. The enzyme was stable between $\mathrm{pH} 5.0$ and 9.0 and activity was lost completely after incubation at $30^{\circ} \mathrm{C}$ for $3 \mathrm{~h}$ at $\mathrm{pH} 3.0$ in $0.2 \mathrm{M}$-citrate buffer. This $\mathrm{pH}$-activity profile is similar to those of other Bacillus $\beta$-amylases (Higashihara \& Okada, 1974; Shinke et al., 1975a, b; Fogarty \& Griffin, 1975; Takasaki, 1976b), particularly the reduced activity and instability at low $\mathrm{pH}$. Plant $\beta$-amylases, on the other hand, generally show maximum activity around $\mathrm{pH} 5 \cdot 0$ (French, 1960).

The optimum temperature for amylase activity was about $50{ }^{\circ} \mathrm{C}$ under the standard assay conditions and above this temperature activity declined sharply. This is similar to other bacterial $\beta$-amylases (Higashihara \& Okada, 1974; Shinke et al., 1975b; Takasaki, $1976 b$ ) with the exception of the $B$. polymyxa enzyme which showed maximal activity at $37^{\circ} \mathrm{C}$ with only $20 \%$ activity remaining after $1 \mathrm{~h}$ at $45^{\circ} \mathrm{C}$ (Fogarty \& Griffin, 1975). These bacterial enzymes are therefore less thermostable than their plant counterparts (Robyt \& Whelan, 1968).

The dialysed supernatant was tested for some other hydrolytic activities and found to be inactive against the following substrates: $p$-nitrophenyl $\alpha$-D-glucopyranoside, maltose, $\alpha, \alpha-$ trehalose, $\beta, \beta$-trehalose, cellobiose, cellodextrin, laminarin, $\beta$-glucan and pullulan. It did not synthesize sugars from glucose but it did attack starch to yield maltose. The major carbohydrate-metabolizing activity was therefore $\beta$-amylase.

The enzyme was partially purified by ion-exchange chromatography; major (I) and minor (II) fractions were recovered. These activities were further characterized. The extent of degradation of starch and amylose by an enzyme is an important criterion of its action type (Manners, 1962). The extent of conversion of starch to maltose was $57 \%$ for fraction I and $60 \%$ for fraction II and this degradation was accompanied by a decrease in the iodine-staining power of $58 \%$ in each case. Amylose was degraded by $72 \%$ (fraction I) and $70 \%$ (fraction II), very similar to the $70 \%$ hydrolysis of potato amylose by crystalline plant $\beta$-amylase (Robyt \& Whelan, 1968). Amylolysis of starch by exo-attacking enzymes is accompanied by a large release of reducing power but relatively little reduction of the iodine-staining capacity of the substrate. Conversely, endo-attacking enzymes rapidly reduce the iodine-staining capacity but release relatively little reducing power. The action pattern for fractions I and II (Fig. 2) followed the exo-pattern, typical of a $\beta$-amylase. A curve for the endo-attacking enzyme, $\alpha$-amylase from Bacillus licheniformis NCIB 6346, is included for comparison.

The action patterns of fractions I and II on malto-oligosaccharides were consistent with 


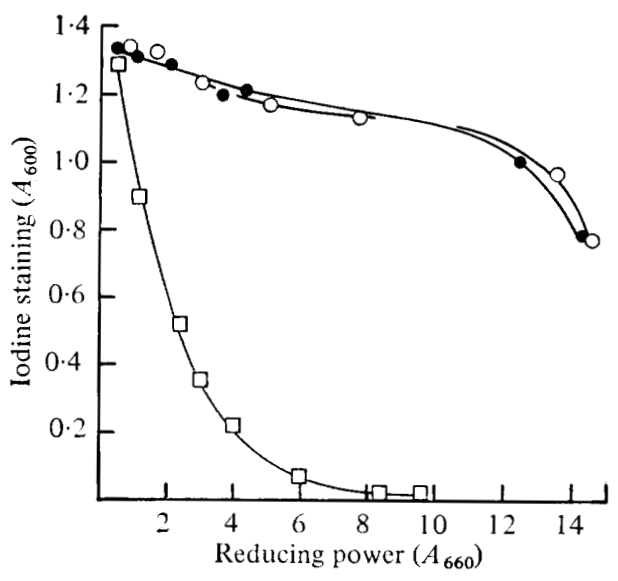

Fig. 2. Release of reducing power from starch and reduction of iodine-staining capacity during hydrolysis by $\beta$-amylase. Starch was incubated for $48 \mathrm{~h}$ with: 0 , fraction I; $\bigcirc$, fraction II; $\square$, culture supernatant from $B$. licheniformis NCIB 6346. For details, see text.

the splitting of maltosyl units from the non-reducing ends of the molecules. Thus, maltotetraose was hydrolysed slowly to maltose, and maltopentaose yielded maltose and maltotriose. Higher maltosaccharides yielded maltose as the predominant product. In a similar experiment, there was no action by either fraction on maltosyl-Schardinger dextrin indicating that debranching activity was absent.

Ion-exchange chromatography of dialysed culture supernatant in the absence of mercaptoethanol resulted in major loss of amylase activity suggesting that the thiol groups of the protein were required in reduced form for stability and activity. This was further analysed by assessing enzyme inhibition by $p$-CMB. Within $30 \mathrm{~min}$ at $22{ }^{\circ} \mathrm{C}$, enzyme activity was reduced to $25 \%$ of its original value by treatment with $0.5 \mathrm{~mm}$ (final concn) $p$-CMB. After $60 \mathrm{~min}$ the activity was reduced to $15 \%$. Cysteine reactivated the enzyme to $65 \%$ and $44 \%$, respectively. In this respect, the $\beta$-amylase from strain NCIB 7581 resembled other bacterial (Higashihara \& Okada, 1974; Fogarty \& Griffin, 1975; Takasaki, 1976b) and plant (French, 1960) $\beta$-amylases which are similarly inactivated by $p$-CMB.

Final verification that strain NCIB 7581 was producing a $\beta$-amylase was obtained by measuring the mutarotation of the maltose produced from amylopectin over $48 \mathrm{~h}$. The upward change in optical rotation indicated that the maltose was in fact initially produced with a $\beta$-configuration.

Since $B$. megaterium NCIB 7581 and $B$. megaterium no. 32, which conforms to the description of $B$. carotarum (Gibson \& Gordon, 1974), both secrete $\beta$-amylase, some explanation is required to account for their different hydrolysis reactions when grown on starch nutrient agar. Evidence for secretion of the debranching enzyme pullulanase can be readily obtained by incubating cultures on pullulan agar (Morgan et al., 1979). Strain NCIB 7581 and several other strains of $B$. megaterium sensu stricto readily hydrolysed the pullulan in this medium indicating that they synthesized a pullulanase. The absence of a pullulan-hydrolysing activity in the culture supernatant from strain NCIB 7581 (see above) suggests that either the cultural conditions were not suitable for pullulanase synthesis (or secretion) or that the enzyme was labile and denatured during the $24 \mathrm{~h}$ dialysis period. Strain NRS 986, on the other hand, which was recently classified as ' $B$. carotarum' (Priest et al., 1980), failed to hydrolyse the pullulan in pullulan agar after incubation for $4 \mathrm{~d}$ at $30{ }^{\circ} \mathrm{C}$. It is possible, therefore, that the clear hydrolysis zone observed after growth of $B$. megaterium sensu stricto on starch agar may be due to the combined action of a $\beta$-amylase and pullulanase while the hazy zones from strains conforming to B. carotarum (Gibson \& 
Gordon, 1974) may be the result of $\beta$-amylolysis of the starch yielding $\beta$-limit dextrins. We are currently studying the extracellular enzymes from strains of $B$. megaterium and related taxa to characterize the various $\alpha$-glucan-hydrolysing systems more fully.

\section{REFERENCES}

Claus, D. \& Hunger, W. (1980). Taxonomic studies on Bacillus megaterium and on agarolytic Bacillus strains. In Classification and Identification of Aerobic Endospore-forming Bacteria. Edited by R. C. W. Berkeley \& M. Goodfellow. London: Academic Press. (In the Press.)

Dubois, M., Gilles, K. A., Hamilton, J. K., Rebers, P. A. \& Smith, F. (1956). Colorimetric method for the determination of sugars and related substances. Analytical Chemistry 28, 350356.

Fogarty, W. M. \& Griffin, P. J. (1975). Purification and properties of $\beta$-amylase produced by Bacillus polymyxa. Journal of Applied Chemistry and Biotechnology 25, 229-238.

French, D. (1960). $\beta$-Amylases. In The Enzymes, vol. 4A, pp. 345-368. Edited by P. D. Boyer, H. Lardy \& K. Myrback. London \& New York: Academic Press.

Gibson, T. \& Gordon, R. E. (1974). Bacillus. In Bergey's Manual of Determinative Bacteriology, 8th edn, pp. 529-550. Edited by R. E. Buchanan \& N. E. Gibbons. Baltimore: Williams \& Wilkins.

Gordon, R. E., Haynes, W. C. \& Pang, C. H.-N. (1973). The Genus Bacillus. Washington, D.C.: United States Department of Agriculture.

Griffin, P. J. \& Fogarty, W. M. (1973). Production of an amylolytic enzyme by Bacillus polymyxa in batch cultures. Journal of Applied Chemistry and Biotechnology 23, 301-308.

Higashihara, M. \& Okada, S. (1974). Studies on $\beta$-amylase of Bacillits megaterium No. 32. Agricultural and Biological Chemistry 38, 1023-1029.

Logan, N. A. \& Eerkeley, R. C. W. (1980). Classification of the genus Bacillus based upon the API system. In Classification and Identification of Aerobic Endospore-forming Bacteria. Edited by R. C. W. Berkeley \& M. Goodfellow. London: Academic Press. (In the Press.)

MANNERS, D. J. (1962). Enzymic synthesis and degradation of starch and glycogen. Advances in Carbohydrate Chemistry 17, 371-430.

MANners, D. J. \& STARK, J. R. (1974). $\alpha$-(1-4)-Dglucans. Part XXII. The iodine staining properties of linear maltosaccharides. Die Starke 26, 78-81.
Miller, G. L. (1959). Protein determination for large numbers of samples. Analytical Chemistry 31, 964-966.

Morgan, F. J., Adams, K. R. \& Priest, F. G. (1979). A cultural method for the determination of pullulan-degrading enzymes in bacteria and its application to the genus Bacillus. Journal of Applied Bacteriology 46, 291-294.

Priest, F. G. (1977). Extracellular enzyme synthesis in the genus Bacillus. Bacteriological Reviews 41, 711-753.

Priest, F. G., Goodfellow, M. \& Todd, C. (1980). The genus Bacillus, a numerical analysis. In Classification and Identification of Aerobic Endospore-forming Bacteria. Edited by R. C.W. Berkeley \& M. Goodfellow. London: Academic Press. (In the Press.)

Robyt, J. F. \& Whelan, W. J. (1968). The $\beta$ amylases. In Starch and Its Derivatives, 4th edn, pp. 477-497. Edited by J. A. Radley. London: Chapman and Hall.

Shinke, R., Kunimi, Y. \& Nishira, H. (1975a). Isolation and characterization of $\beta$-amylase producing micro-organisms. Journal of Fermentation Technology 53, 687-692.

Shinke, R., Kunimi, Y. \& Nishira, H. (1975b). Production and some properties of $\beta$-amylases of Bacillus sp. BQ10. Journal of Fermentation Technology 53, 693-697.

Smith, N. R., Gordon, R. E. \& Clark, F. E. (1952). Aerobic Spore-forming Bacteria. Washington, D.C.: United States Department of Agriculture.

TAKASAKI, Y. (1976a). Productions and utilizations of $\beta$-amylase and pullulanase from Bacillus cereus var. mycoides. Agricultural and Biological Chemistry 40, 1515-1522.

TAKASAKI, Y. (1976b). Purification and enzymatic properties of $\beta$-amylase and pullulanase from Bacillus cereus var. mycoides. Agricultural and Biological Chemistry 40, 1523-1530.

Trevelyan, W. E., Procter, D. P. \& Harrison, J. S. (1951). Detection of sugars on paper chromatograms. Nature, London 166, 444-445. 